\title{
Sarcoidosis Initially Manifesting as Symptomatic Hypercalcemia with the Absence of Organic Involvement
}

\author{
Kouka Motoyama, Masaaki Inaba, Masanori Emoto, Hirotoshi Mori and Yoshiki Nishizawa
}

\begin{abstract}
A 53-year-old man was admitted to Osaka City University Hospital on July 21, 1998, for investigation of symptomatic hypercalcemia. Laboratory data on admission revealed that serum $\mathrm{Ca}$ had increased to around $12.6 \mathrm{mg} / \mathrm{dl}$ and there was a significant increase in urinary Ca excretion. The serum phosphate level remained normal. Although the serum PTH level was below the detection limit, serum 1,25-dihydroxyvitamin $\mathrm{D}\left(1,25(\mathrm{OH})_{2} \mathrm{D}\right)$ was increased. Diagnosis of sarcoidosis was supported by a negative tuberculin test and by the elevated levels of serum angiotensin-converting enzyme (ACE), lysozyme activity, and CD4/CD8 ratio in bronchoalveolar lavage specimen; there was however no imaging evidence of sarcoidosis such as bilateral hilar lymphnode enlargement on chest X-ray, high resolution $\mathrm{CT}$ or ${ }^{67} \mathrm{Ga}$ citrate scintigraphy. Biopsy specimens from the cervical lymphnode revealed no epitheloid cell granulomas or giant cells. Administration of prednisolone achieved a decrease in serum $\mathrm{ACE}$ and $1,25(\mathrm{OH})_{2} \mathrm{D}$ levels, followed by restoration of serum Ca and urinary Ca excretion to the normal range, and finally by an increase of serum PTH to the normal level. These observations suggested that the hypercalcemia could be explained by extrarenal production of $1,25(\mathrm{OH})_{2} \mathrm{D}$. We report here on this rare case of sarcoidosis with initial symptoms of symptomatic hypercalcemia resulting from extrarenal production of $1,25(\mathrm{OH})_{2} \mathrm{D}$.
\end{abstract}

(Internal Medicine 41: 449-452, 2002)

Key words: 1 alpha, 25-dihydroxyvitamin D, hypercalcinuria, vitamin D, sarcoidosis, hypercalcemia

\section{Introduction}

Sarcoidosis is a systemic granulomatous disease of unknown etiology which occasionally involves other organ systems, including the lymphnodes, eyes, nervous system, kidneys, gas- trointestinal tract, heart, and skin (1). Most patients are diagnosed incidentally on the basis of characteristic chest X-ray abnormalities which appear in around $95 \%$ of cases, including those with no specific symptoms $(2,3)$.

Although hypercalcemia occurs in $10-20 \%$ of Caucasian sarcoidosis patients, it is quite rare in Japanese patients (3). Moreover, hypercalcemia is usually preceded by other signs characteristic of sarcoidosis $(4,5)$. There has therefore been no case reported thus far of a Japanese patient initially presenting with hypercalcemia and later being diagnosed with sarcoidosis.

We report in the present paper on an interesting case that presented with serum Ca levels elevated as high as $12.6 \mathrm{mg} / \mathrm{dl}$ and was later diagnosed with sarcoidosis on the evidence of elevated levels of angiotensin-converting enzyme (ACE), gammaglobulin and lysozyme activity, negative tuberculin test, and elevated CD4/CD8 ratio in bronchoalveolar lavage (BAL), but that had no chest $\mathrm{X}$-ray finding characteristic of sarcoidosis, such as bilateral hilar enlargement (BHL).

\section{Case Report}

A 53-year-old-man was admitted to Osaka City University Hospital with hypercalcemia on July 21, 1998. Lymphnode biopsy from the anterior scalenus muscle, performed when he was 43 years old because of an abnormal shadow in chest Xray, had not disclosed sarcoidosis. He had been well until May 1998, when he noticed thirst, polydipsia and polyuria. A visit to a nearby hospital revealed hypercalcemia $(12.9 \mathrm{mg} / \mathrm{dl})$ with absence of hypophosphatemia and impaired renal function. Then he was referred to our hospital for further investigation. The patient had neither a family history of hypercalcemia nor a past history of urinary stones, bone pain, pathological fracture, metabolic bone disease, and had not taken any medicine that might affect $\mathrm{Ca}$ metabolism.

On admission, the patient was $175.0 \mathrm{~cm}$ tall and weighed $58.8 \mathrm{~kg}$. Blood pressure was $154 / 92 \mathrm{mmHg}$, and pulse was regular at 80 per minute. The appearance of the skin and tongue was suggestive of dehydration, but there was no finding suggestive of sicca syndrome such as dry eye, coated tongue, or

From the Department of Metabolism Endocrinology and Molecular Medicine, Osaka City University Graduate School of Medicine, Osaka

Received for publication November 13, 2000; Accepted for publication January 15, 2002

Reprint requests should be addressed to Dr. Koka Motoyama, the Department of Metabolism Endocrinology and Molecular Medicine, Osaka City University Graduate School of Medicine, 1-4-3 Asahi-machi, Abeno-ku, Osaka 545-8585 


\section{Motoyama et al}

tooth decay. No systemic lymphnode enlargement or abnormal subcutaneous nodules were found, the skin, lung, heart and abdomen appeared normal, no abnormality was observed on neurological examination, and no peripheral edema was found.

Laboratory data on admission are shown in Tables 1 and 2. Urinalysis was normal. CBC indicated the presence of normocytic, normochromic anemia. Creatinine clearance was reduced to $55 \mathrm{ml} / \mathrm{min}$, indicative of impaired renal function. Serum levels of total and ionized Ca were increased in spite of normophosphatemia. The plasma intact PTH level was suppressed to an undetectable level. Nephrogenous cAMP and
\%TRP were normal. Serum level of PTH-related peptide (PTHrP), measured using antibody to c-peptide of PTHrP, was within normal range. Although serum intact-PTH was suppressed, serum $1,25(\mathrm{OH})_{2} \mathrm{D}$ was increased to above the normal upper limit; serum $25(\mathrm{OH}) \mathrm{D}$ and $24,25(\mathrm{OH})_{2} \mathrm{D}$ were within the normal range. Daily urinary $\mathrm{Ca}$ excretion was markedly increased to $750 \mathrm{mg}$, although biochemical markers for bone resorption such as urinary excretion of hydroxyproline, pyridinoline and deoxypyridinoline remained around the normal upper limit. Of the major bone formation markers, including alkaline phosphatase, only serum osteocalcin was increased.

Serum ACE was elevated to twice the normal level. Gamma-

Table 1. Laboratory Data on Admission (1)

\begin{tabular}{|c|c|c|c|c|c|}
\hline Urinalysis & & WBC & $6,600 / \mu \mathrm{l}$ & T-BIL & $0.7 \mathrm{mg} / \mathrm{dl}$ \\
\hline $\mathrm{pH} 6.0$ & & Bas & $1.1 \%$ & AST & $18 \mathrm{IU} / l$ \\
\hline Glucose & $(-)$ & Eos & $2.4 \%$ & ALT & $20 \mathrm{IU} / l$ \\
\hline Protein & $(-)$ & Seg & $65.7 \%$ & ALP & $129 \mathrm{IU} / \mathrm{l}$ \\
\hline Blood & $(-)$ & Ly & $22.5 \%$ & CHE & $393 \mathrm{IU} / /$ \\
\hline \multirow[t]{2}{*}{ Ketone } & $(-)$ & Mono & $8.3 \%$ & LDH & $225 \mathrm{IU} / /$ \\
\hline & & PL-C & $30.0 \times 10^{4} / \mu \mathrm{l}$ & $\gamma$-GTP & $54 \mathrm{IU} / l$ \\
\hline Sediment & & & & CK & $33 \mathrm{IU} / l$ \\
\hline $\mathrm{RBC}$ & $1-2 / \mathrm{HPF}$ & TP & $7.1 \mathrm{~g} / \mathrm{dl}$ & BUN & $25 \mathrm{mg} / \mathrm{dl}$ \\
\hline \multirow{2}{*}{ WBC } & $2-3 / \mathrm{HPF}$ & $\mathrm{Alb}$ & $3.8 \mathrm{~g} / \mathrm{dl}$ & CRE & $1.3 \mathrm{mg} / \mathrm{dl}$ \\
\hline & & $\alpha_{1}-\mathrm{glb}$ & $2.5 \%$ & UA & $8.3 \mathrm{mg} / \mathrm{dl}$ \\
\hline $\mathrm{RBC}$ & $448 \times 10^{4} / \mu 1$ & $\alpha_{2}$-glb & $8.6 \%$ & $\mathrm{Na}$ & $140 \mathrm{mEq} / \mathrm{l}$ \\
\hline $\mathrm{Hb}$ & $13.4 \mathrm{~g} / \mathrm{dl}$ & $\beta$-glb & $8.9 \%$ & $\mathrm{~K}$ & $4.2 \mathrm{mEq} / \mathrm{l}$ \\
\hline $\mathrm{Ht}$ & $39.8 \%$ & $\gamma-\mathrm{glb}$ & $21.1 \%$ & $\mathrm{Cl}$ & $100 \mathrm{mEq} / \mathrm{l}$ \\
\hline
\end{tabular}

WBC: White blood cell, RBC: Red blood cell, Hb: Hemoglobin, Ht: Hematocrit, Bas: basophil, Eos: eosinophil, Seg: segmented leukocyte, Ly: lymphocyte, Mono: monocyte, PL-C: platelet, TP: total protein, Alb: albmin, $\alpha_{1}$-glb: $\alpha_{1}$ globulin, $\alpha_{2}$-glb: $\alpha_{2}$ globulin, $\beta$-glb: $\beta$ globulin, $\gamma$-glb: $\gamma$ globulin, T-BIL: total bilirubin, AST: aspartate amoinotransferase, ALT: alanine amoinotransferase, ALP: alkaline phosphatase, CHE: choline esterase, LDH: lactate dehydorogenase, $\gamma$-GTP: gamma glutamic pyruvic transaminase, $\mathrm{CK}$ : creatine phosphokinase, BUN: blood urea nitrogen, CRE: creatinine, UA: uric acid.

Table 2. Laboratory Data on Admission (2)

\begin{tabular}{|c|c|c|c|}
\hline \multicolumn{2}{|c|}{ Arterial blood gas analysis } & $\mathrm{Ca}$ & $12.6 \mathrm{mg} / \mathrm{dl}$ \\
\hline $\mathrm{pH}$ & 7.439 & $\mathrm{Ca}^{++}$ & $3.18 \mathrm{mEq} / \mathrm{l}$ \\
\hline $\mathrm{pCO}_{2}$ & $43.0 \mathrm{mmHg}$ & IP & $3.3 \mathrm{mg} / \mathrm{dl}$ \\
\hline $\mathrm{pO}_{2}$ & $77.0 \mathrm{mmHg}$ & $\mathrm{U}-\mathrm{Ca}$ & $742 \mathrm{mg} /$ day \\
\hline $\mathrm{BE}$ & $4.4 \mathrm{mEq} / \mathrm{l}$ & U-IP & $1,152 \mathrm{mg} /$ day \\
\hline \multirow[t]{2}{*}{$\mathrm{HCO}_{3}^{-}$} & $28.7 \mathrm{mEq} / \mathrm{l}$ & & \\
\hline & & Intact-PTH & $<10 \mathrm{pg} / \mathrm{ml}$ \\
\hline $\mathrm{ACE}$ & $51.8 \mathrm{IU} / l(7.0-25.0)$ & c-PTHrP & $40.4 \mathrm{pmol} / \mathrm{l}$ \\
\hline Lysozyme & $43.8 \mu \mathrm{g} / \mathrm{ml}(3.4-8.6)$ & PTH-HS & $<50 \mathrm{pg} / \mathrm{ml}$ \\
\hline Broncho alveola & lavage & $1.25(\mathrm{OH})_{2} \mathrm{D}$ & $\begin{array}{r}77.7 \mathrm{pg} / \mathrm{ml} \\
(59.7 \pm 14.1)\end{array}$ \\
\hline $\begin{array}{l}\text { Total cell count } \\
\text { lymphcyte }\end{array}$ & $\begin{array}{r}1.57 \times 10^{5} / \mathrm{ml} \\
36 \%(10.69 \pm 6.99)\end{array}$ & $25(\mathrm{OH}) \mathrm{D}$ & $\begin{array}{l}17.4 \mathrm{ng} / \mathrm{ml} \\
(14.8 \pm 5.8)\end{array}$ \\
\hline $\mathrm{CD} 4 / \mathrm{CD} 8$ & $2.86(1.18-2.08)$ & $24,25(\mathrm{OH})_{2} \mathrm{D}$ & $\begin{array}{r}1.14 \mathrm{ng} / \mathrm{ml} \\
(1.08 \pm 0.26)\end{array}$ \\
\hline
\end{tabular}

BE: base excess, U-Ca: urinary Ca, IP: serum phosphate, U-IP: urinary phosphate. 
globulin and lysozyme activities were also elevated. Tuberculin and tetanus toxoid skin tests were both negative, as was adult $\mathrm{T}$ cell leukemia antibody test. BAL analysis showed the proportion of lymphocytes as high as $36 \%$ with a significant increase in CD4/CD8 ratio to 2.86. These data were all supportive of the diagnosis of sarcoidosis.

Chest X-ray and high-resolutional computed tomographic lung scan did not however show any abnormalities such as BHL or reticular shadow in the lung field and ${ }^{67} \mathrm{Ga}$ citrate systemic scan did not detect any pathologic uptake. Spirometer and arterial blood gas analysis also showed no abnormality. Heart dysfunction was not found on electrocardiogram or ultrasonic cardiogram. Scintigraphy for parathyroid and for bone did not show any spot with abnormally high uptake. No nodular lesion was observed in ultrasonic examination, gastrofiberscope or fundoscopy. We then performed a biopsy under ultrasonic echo guidance from one of the enlarged paracarotid lymph nodes. The result was however negative for sarcoidosis due to the absence of any confluent epithelioid cell granuloma or giant cells.

The data presented above led us to diagnose the patient as having sarcoidosis and to conclude that hypercalcemia resulted from extrarenal activation of vitamin D from 25-OH-D to $1,25(\mathrm{OH})_{2} \mathrm{D}$. We therefore examined the effect of glucocorti- coid on the hypercalcemia. Treatment was introduced with an initial dose of $20 \mathrm{mg} /$ day prednisolone. Serum ACE and $1,25(\mathrm{OH})_{2} \mathrm{D}$ levels had declined rapidly to $17.4 \mathrm{IU} / l$ and 17.7 $\mathrm{pg} / \mathrm{ml}$, respectively, at 7 days after the start of prednisolone, followed by reductions of serum $\mathrm{Ca}$ and urinary $\mathrm{Ca}$ excretion to $8.8 \mathrm{mg} / \mathrm{dl}$ and $280 \mathrm{mg} /$ day at 14 days after the start of prednisolone, when serum intact-PTH increased from an undetectable level to $18.8 \mathrm{pg} / \mathrm{dl}$ (Fig. 1). Although the prednisolone dose had been tapered gradually and then finally stopped at 6 months after the start of administration, serum $\mathrm{Ca}$ level remained normal at $8.8 \mathrm{mg} / \mathrm{dl}$. Serum $\mathrm{P}$ also remained around $3.0 \mathrm{mg} / \mathrm{dl}$. There is no sign of recurrence thereafter for two years following prednisolone withdrawal.

\section{Discussion}

Sarcoidosis is a systemic disease characterized by epithelioid granuloma and often accompanied by hypercalcemia. The incidence of this complication is reported to be $10-20 \%$ in Europe and the USA, but in Japan is as low as 5.6-14.3\% (2, $3)$. Extrarenal production of $1,25(\mathrm{OH})_{2} \mathrm{D}$ is the main mechanism for development of hypercalcemia in sarcoidosis $(6,7)$. In certain granulomatous diseases such as sarcoidosis, various

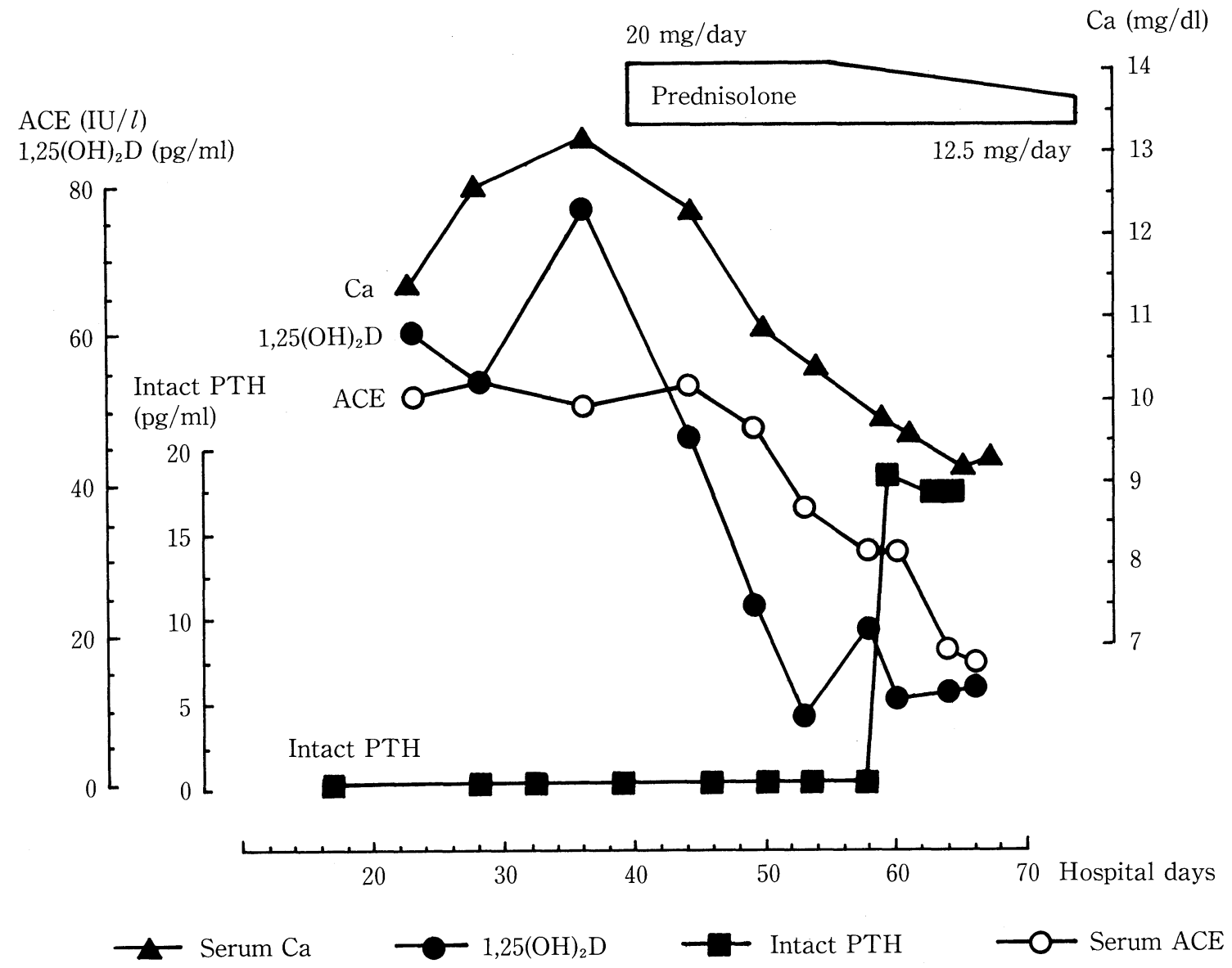

Figure 1. Clinical course. 
cytokines are known to induce $25(\mathrm{OH}) \mathrm{D}-1 \alpha$-hydroxylase in macrophages, in which serum ACE, a marker for macrophage activation, is often elevated $(8,9)$. Therefore, hypercalcemic sarcoid patients show abnormally high $1,25(\mathrm{OH})_{2} \mathrm{D}$ levels in spite of having undetectable levels of intact PTH (7). Since induction of $25(\mathrm{OH}) \mathrm{D}-1 \alpha$-hydroxylase in macrophages is glucocorticoid-sensitive and elevation of serum $1,25(\mathrm{OH})_{2} \mathrm{D}$ in the present case was normalized by glucocorticoid administration $(10,11)$, the hypercalcemia seems to have been caused mainly by extrarenal production of $1,25(\mathrm{OH})_{2} \mathrm{D}(12,13)$. In the present case, serum $1,25(\mathrm{OH})_{2} \mathrm{D}$ level was high relative to levels of serum 25(OH)D, even though serum intact-PTH level was low, suggesting activation of vitamin D in a PTH-independent way. Since glucocorticoid administration very effectively normalized serum $\mathrm{Ca}$ and serum $1,25(\mathrm{OH})_{2} \mathrm{D}$, the mechanism of serum $1,25(\mathrm{OH})_{2} \mathrm{D}$ elevation seems to have been glucocorticoidsensitive extrarenal production of $1,25(\mathrm{OH})_{2} \mathrm{D}$. Since hypercalcemia in sarcoid patients is usually preceded by overt, well established multioganic disease, few cases presenting initially with hypercalcemia have been reported. No less than $95 \%$ of patients have abnormal chest X-ray findings characteristic of sarcoidosis on diagnosis $(5,6)$. As far as we know, only about 10 patients have been reported to show hypercalcemia in the absence of any abnormal chest X-ray findings $(14,15)$. The present patient showed none of the abnormal ultrasound examination findings characteristic of sarcoidosis, such as subcutaneous tumor, neurological abnormality, on nodular lesions in the liver, spleen, or kidney. Furthermore, urine protein test was negative, and no gastric polyp or nodular lesion was found in gastrofiberscope examination. The only finding characteristic of sarcoidosis was an increase in lymphocyte count and in CD4/CD8 ratio in BAL specimens; no pulmonary evidence of sarcoidosis was detected on chest X-ray, CT scan or ${ }^{67} \mathrm{Ga}$ citrate scintigraphy. Since activated pulmonary macrophages are capable of producing $1,25(\mathrm{OH})_{2} \mathrm{D}$ even in the absence of sarcoid granuloma (12), it seems reasonable that the present case with the absence of any organ involvement showed an elevation in serum $1,25(\mathrm{OH})_{2} \mathrm{D}$ level.

To conclude, the present patient with sarcoidosis was rare enough to be noteworthy in that this case presented without apparent organic involvement. The mechanism by which hypercalcemia developed was probably due to extrarenal production of $1,25(\mathrm{OH})_{2} \mathrm{D}$.

\section{References}

1) Allegri L, Olivetti G, David S, Concarı GM, Dascola G, Savazzi G. Sarcoid granulomatous nephritis with isolated and reversible renal failure. Nephron 25: 207-208, 1980.

2) Adams JS. Vitamın D metabolite-mediated hypercalcemia. Endocrinol Metab Clın North Am 18: 765-778, 1989.

3) Mimura Y, Maeshıma Y, Ogura T. A patıent with sarcoidosis associated with recurrent urolithiasis and tubular injury caused by calcium depositıon. Jpn J Nephrol 38: 141-145, 1996.

4) Chapelon C, Ziza JM, Piette JC, et al. Neurosarcordosis: signs, course and treatment in 35 confirmed cases. Medıcine (Baltimore) 69: 261-276, 1990.

5) Freitag J, Gobel U, Passfall J, Kettritz U, Schneider W, Luft FC. Consider sarcoidosis in patients with nephrocalcinosis, even if the chest roentgenogram is normal. Nephrol Dial Transplant 12: 2161-2165, 1997.

6) Basile JN, Liel Y, Shary J, Bell NH. Increased calcium intake does not suppress circulating 1,25-dihydroxyvitamin $\mathrm{D}$ in normocalcemic patients with sarcoidosis. J Clin Invest 91: 1396-1398, 1993.

7) Kalantar-Zadeh K, Neumayer HH, Wunsch PH, Luft FC. Hypercalcemia and sarcoidosis in an anephric dialysis patient. Nephrol Dial Transplant 9: 829-831, 1994.

8) Barbour GL, Cobunrn JW, Slatopolsky E, Norman AW, Horst RL. Hypercalcemia in an anephric patient with sarcoldosis. N Engl J Med 305: 440443, 1981.

9) Bell NH, Stern PH, Pantzer E, Sinha TK, DeLuca HF. Evidence that increased circulatıng 1 alpha, 25-dihydroxyvitamin $\mathrm{D}$ is the probable cause for abnormal calcium metabolism in sarcoidosis. J Clin Invest 64: 218225, 1979.

10) Adams JS, Modlın RL, Diz MM. Barnes PF Potentiation of macrophage 25(OH)D1-Hydroxylation reaction by human tuberculous pleural effusion fluid. J Clin Endocrinol Metab 69: 457-462, 1984.

11) Koeffler HP, Reichel H, Bishop JE, Norman AW. $\gamma$ Interferon stimulates production of 1, 25-dihydroxyvitamin D3 by normal human macrophages. Biochem Biophys Res Commun 127: 596-603, 1985.

12) Adams JS, Sharma OP, Gacad MA, Singer FR. Metabolism of 25hydroxyvitamin D3 cultured pulmonary alveolar macrophages in sarcoldosis. J Clın Invest 72: 1856-1860, 1983.

13) Thomas PD, Hunnınghake GW. Current concepts of the pathogenesis of sarcoidosis. Am Rev Respir Dis 135: 747-760, 1987.

14) Evron E, Goland S, von der Walde J, Schattner A, Sthoeger ZM. Idiopathic calcitriol-1nduced Hypercalcemia. A new disease entity? Arch Intern Med 157: 2142-2145, 1997.

15) Gupta VK. Steroid-responsive hypercalcemic nephropathy in diabetes mellitus probably due to occult sarcoidosis. Nephron 74: 214-215, 1996 (letter). 